\title{
The Effect of Pioglitazone on Matrix Metalloproteinase-9, Matrix Metalloproteinase-2, Tumor Necrosis Factor- $\alpha$, Vascular Endothelial Growth Factor and E-Selectin in Skin Lesions in Psoriatic Patients with and without Psoriatic Arthritis
}

\author{
Seham M. S.EL - Nakeeb*, Sahar Fawzy**, Magda H Osman*** \\ Biochemistry* Dermatology and Veneriology ** Clinical Pathology*** Dept. \\ Faculty of Medicine for Girls AL - Azhar University
}

\begin{abstract}
Background: Psoriasis is a common inflammatory skin disease characterized by infiltration of inflammatory cells into the epidermis and altered keratinocyte differentiation. The aim of the present study was to investigate the role of MMP-9 in the development of psoriasis by assessing the presence of MMP-9 in lesional skin and in sera of psoriatic patients with \& without psoriatic arthritis, the association of MMP-9 with the activity of the disease, the relationship between MMP-9 and TNF- $\alpha$ production as well as to evaluate the effect of pioglitazone (one of the agents thiazolidinediones) on TNF- $\alpha$, MMP-9, MMP-2, VEGF and Eselectin production and in treatment of psoriasis.

Subjects and Methods: Thirty-five psoriatic patients ( 28 males, 7 females) were included in this study. They were divided into 2 groups. Group I (PsA) included 15 psoriatic patients, clinically presenting joint symptoms associated to the cutaneous disease (PsA). Group II (Ps) included 20 psoriatic patients, clinically presenting cutaneous disease without psoriatic arthritis (PsA). Each psoriatic patient received pioglitazone $30 \mathrm{mg} /$ day orally for 10 weeks. Lesional tissue specimens were taken, in the same skin area before and after 10 weeks pioglitazone treatment. Tissues were kept in short term cultures and production soluble mediators such as TNF- $\alpha$, MMP-9, MMP-2, VEGF and E-selectin, which include angiogenic molecules associated to the development of plaque psoriasis, were measured in the culture supernatants by ELISA. MMP-9 concentrations were also measured in the sera. The cutaneous activity of disease was evaluated by the Psoriasis Area and Severity Index (PASI).

Results: Clinical and laboratory assessment indicated that all patients had a significant improvement of the PASI score after 10 weeks of pioglitazone therapy. The clinical improvement was associated to a significant decrease of TNF- $\alpha$, MMP-9, MMP-2, VEGF\& Eselectin levels $(\mathrm{P}<0.05)$, spontaneously released by lesional biopsies before and after therapy. A significant decrease of MMP-9 $(\mathrm{P}<0.01)$ in the sera, associated to the clinical improvement was also found. In addition, significant positive correlations $(\mathrm{P}<0.01)$ were found between the TNF- $\alpha$ and PASI score, MMP-9, MMP-2, VEGF\& E-selectin ( $\mathrm{r}=0.85,0.84,0.58,0.63,0.67$ respectively), as well as between the MMP-9 and PASI, MMP-2, VEGF\& E-selectin ( $\mathrm{r}=0.82$, $0.39,0.69,0.41$ respectively) of patients with PsA after pioglitazone treatment. In psoriatic patients without psoriatic arthritis after pioglitazone treatment there were also significant positive correlations between the TNF- $\alpha$ and PASI score ,MMP-9, MMP-2, VEGF\& Eselectin( $\mathrm{r}=.0 .87,0.68,0.53,0.61,0.51$ respectively), as well as between MMP-9 and PASI, MMP-2, VEGF\& E-selectin ( $\mathrm{r}=0.95,0.51,0.58,0.45$ respectively).

Conclusion: The current study shows the existence of a direct relationship between MMP9 and TNF- $\alpha$ production strongly suggesting that MMP-9 may play a key role in the skin inflammatory process. Our findings also demonstrated that pioglitazone could be considered as an efficacious and safe agent for the treatment of psoriasis. The optimum dose and duration of pioglitazone therapy remain to be determined.
\end{abstract}

Key words: Psoriasis . Psoriatic arthritis . Matrix metalloproteinase-9 . Pioglitazone 


\section{Introduction}

Psoriasis is a chronic inflammatory skin disease characterized by hyperproliferation of epidermal cells with prominent blood vessels and a thick perivascular lymphocytic infiltrate (Camp, 1998). Epidemiological data demonstrate an association with a number of distinct disorders of the joints (psoriatic arthritis), the intestine (Crohn's disease), and skin (pustular disorders), as well as increased risk of cardiovascular disease (Christophers, 2006). The etiology of psoriasis is still unknown. Whether the disease results from a primary abnormality in epidermal keratinocytes or depends upon a deregulation of the immune system it has been matter of controversial debating (Bos\& De Rie., 1999). Recent evidence, however, indicated that activated lymphocytes and keratinocytes are both required for the development of psoriatic lesion (Sano et al., 2005). In fact, the chronic, self-aggressive, epidermal $\mathrm{T}$ cells activation, characteristic of the disease, might be initiated by common streptococcal infections ( $\beta$-haemolitic streptococci) that, in turn, might trigger a cross immune recognition between streptococcal $M$ proteins and those keratins that are pathologically up-regulated in psoriatic lesions (Johnston et al., 2004). Psoriasis is currently thought of as a T-cell mediated 'Type-1' autoimmune disease. Gene expression changes in psoriasis lesions have been well documented, and strongly support an important role for tumor necrosis factor and interferon gamma signal pathways in its pathogenesis. The strongest genetic determinant of psoriasis identified to date lies within the class I region of the multiple histocompatibility locus antigen cluster, although its low penetrance implicates a requirement for other genetic risk factors. Multiple genomewide linkages and an increasing number of association studies have been carried out, leading to multiple linkage peaks, and the identification of potential low risk variants. A number of these variants lie within genes encoding components of the immune system. However, the functional relationships between predisposing genetic variation are unclear, and presumably involve genetic susceptibility factors affecting both immune cell activation and keratinocyte differentiation. The interaction of environmental trigger factors with genetic effects is also not understood, but provides further evidence for the complex basis of this disease (Shiina et al., 2004 \& Liu, et al., 2006). An auto-immune response may thus be sustained by a mechanism of molecular mimicry. Indeed, psoriatic keratinocytes exhibit an altered phenotype characterized by a costitutive Stat 3 activation (Sano et al., 2005) and a different response to IFN- $\gamma$ compared to normal keratinocytes ( Nickoloff et al., 1989 \& Wrone-Smith et al., 1997).

About one third of patients with psoriasis also suffer of an inflammatory arthritis with clinical and biological features that are partially similar to rheumatoid arthritis (RA) (Gladman \& Rahman, 2001). Although, the systematic classification and the diagnostic criteria for this form of arthritis are still under validation (Helliwell \& Taylor, 2005), psoriatic arthritis (PsA) has been recognized as a clinical entity distinct from RA, due to the absence of the rheumatoid factor as well to the presence of specific clinical features. Articular erosions in PsA occur less commonly than in RA and progression to joint destruction occurs at a slower rate; nevertheless it can lead to disability(McHugh et al.,2003).

Compelling evidences indicate that TNF- $\alpha$ plays a central role in sustaining the psoriatic inflammatory process in skin as well as in joints (Kane \&Fitzgerald, 2004). In psoriatic skin, TNF- $\alpha$ is the prevalent cytokine, it can be produced by several cell types including activated $\mathrm{T}$ cells, keratinocytes, macrophages and Langerhans cells (Lockslay et al., 2001). Moreover, in epidermal keratinocytes, TNF- $\alpha$ regulates genes involved in immune and inflam-matory response, including those involved in cell motility or cytoskeleton changes or in extracellular matrix remodeling (Tomohiro et al., 2004). In the affected joints TNF- $\alpha$ appears as well responsible of the positive regulation and overexpression of chemokines, cytokines and angiogenic molecules which may lead to proliferation and 
activation of sinovial cells that, in turn, lead to cartilage and bone destruction (Hata et al. 2004). Moreover TNF- $\alpha$ has been implicated in promoting osteoclastogenesis in PsA (Ritchlin et al., 2003). Therapeutic approaches based on anti-TNF- $\alpha$ agents have provided indirect evidence in support to this hypothesis, since they are highly effective in controlling both skin and joint manifestations in patients with PsA (Schopf et al., 2002 \& Galadari et al., 2003). Gottlieb (2003), Krueger and Callis (2004) and Mastroianni et al. (2005) demonstrated that the marked improvement in both skin and joint manifestations following therapy with Infliximab, a chimeric monoclonal antibody which binds specifically to human TNF- $\alpha$, was significantly associated to the decrease of serum levels of TNF- $\alpha$, angiogenic molecules and MMP-2. Some data from large placebocontrolled studies have shown that the medication is highly effective (Gottlieb et al., 2004 \& Antoni et al., 2005). Mastroianni et al. (2005) described significant decreases of IL-6, VEGF, FGF-b and E-selectin after early infliximab infusions and the significant correlations between PASI and MMP-2, FGF-b or VEGF. Today there are three main biological agents targeting TNF- $\alpha$, which are already in use for treating PsA. These are the chimeric monoclonal IgG1 antibody infliximab with human constant and murine variable regions, the fully human anti-TNF$\alpha$ monoclonal antibody adalimumab and the recombinant $75-\mathrm{kDa}$ TNF receptor $\mathrm{IgG} 1$ fusion protein etaner-cept (Brandt \& Braun, 2006).

Matrix metalloproteinases (MMPs) have been associated with the remodeling of the extracellular matrix during inflammation, neovascularization, and malignant transformation (Suomela et al., 2003). MMPs belong to a family of proteolytic enzymes that are capable of degrading all components of the extracellular matrix, a key event in the development of cartilage destruction and joint erosion (Parks et al., 2004). Kinetic studies using known model substrates have shown that both MMP2 and MMP9 are most effective in degrading collagen as compared to other MMPs (Mackay et al.,1990) and have been spec- ifically implicated in inflammatory arthritis, including angiogenesis (Fraser et al.,2001, Alenius et al., 2001\& Itoh, et al.,2002). MMPs also have a key role in tissue repair (Pilcher et al., 1999). The endothelial activation VEGF and E-selectin molecules are significantly associated to disease activity in psoriasis plaques (Brushan, et al., 1999 \& Carducci et al., 1999).

Thiazolidinediones (TZDs) are antidiabetic agents that enhance insulin sensitivity through activating peroxisome proliferator-activated receptor (PPAR) gamma. Besides their glucose-lowering effects, TZDs are shown to exhibit anti-inflammatory properties in vascular cells, although their precise molecular mechanisms are unknown (Kurebayashi et al., 2005). TZDs have been shown to reduce plasma levels of the chemokine, monocyte chemotactic protein-1 (MCP-1), the anti-fibrinolytic protein, plasminogen activator inhibitor-1 (PAI-1), the endothelial cell adhesion molecules, Eselectin and inter-cellular adhesion molecule-1 (ICAM-1), the leuc-ocyte-activating molecule, CD40L, and the tissue-remodeling enzyme, matrix metall-oproteinase-9 (Buckingham, 2005). Ligand activation of peroxisome proliferator receptor-gamma (a class of nuclear receptors) by thiazolidinediones can normalize the histologic features of psoriasis. So TZDs could be considered as an efficacious and safe agent for the treatment of plaque psoriasis (Shafiq et al., 2005). Our study aimed to investigate the role of MMP-9 in the development of psoriasis by assessing the presence of MMP-9 in lesional skin and in sera of psoriatic patients with \& without psoriatic arthritis, the association of MMP-9 with the activity of the disease, the relationship between MMP-9 \& TNF- $\alpha$ production as well as to evaluate the effect of pioglitazone (thiazolidinedione) on TNF- $\alpha$, MMP-9, MMP-2, VEGF and E-selectin production and in treatment of psoriasis.

\section{Subjects and Methods}

\section{Subjects}

Thirty-five psoriatic patients (28 males, 7 females) aged 36-63 years were selected for the present study from 
dermatology and rheumatology outpatient clinical at the El- Zahraa and El-Hussein University Hospitals. . They were divided into 2 groups. Group I (PsA) included 15 psoriatic patients (11 males, 4 females) aged 39-63 years, with a clinical diagnosis of psoriatic arthritis (PsA). Group II (Ps) included 20 psoriatic patients without PsA (17males, 3 females), aged 36-62 years. Skin involvement was evaluated with Psoriasis Area and Severity Index (PASI) (Fredriksson \& Pettersson, 1978). Arthritis was evaluated following the American College of Rheumatology criteria (ACR) (Mease et al., 2000) with clinical examination of the tender and swollen joints, laboratory tests of inflammatory markers (erythrocyte sedimentation rate $=\mathrm{ESR}$ and C-reactive protein $=\mathrm{CRP}$ ) and radiological examination of joint damage. Each psoriatic patient received pioglitazone $30 \mathrm{mg} /$ day orally for 10 weeks. All participants gave their informed consent before the study began.

\section{Biochemical analysis}

Venous blood samples $(5 \mathrm{ml})$ were collected after an overnight fasting before and after 10 weeks of pioglitazone treatment. Sera were stored frozen in small aliquots at $-80^{\circ} \mathrm{C}$, till analysis. Lesional tissue specimens (4 $\mathrm{mm}$ punch biopsies) were taken, in the same skin area before and after 10 weeks of pioglitazone treatment. Each tissue sample was rinced in cold sterile medium, weighed after removing fluid excess, and kept in short term culture in a polypropilene tube with $1 \mathrm{ml}$ of complete medium (RPMI 1640 (Sigma,USA), $10 \%$ fetal calf serum (FCS), $2 \mathrm{mM} \mathrm{L-}$ glutamine, antibiotics) in a 5\% $\mathrm{CO} 2$ atmosphere at $37^{\circ} \mathrm{C}$. After $36 \mathrm{hrs}$ of incubation, the supernatant was collected, spinned in a cold microcentrifuge at $1000 \times \mathrm{g}$ and subdivided in small aliquots to be stored frozen at $-80^{\circ} \mathrm{C}$, till analysis. MMP-9, MMP-2, TNF- $\alpha$, VEGF\& E-selectin concentrations released in culture supernatants from the lesional tissue samples were measured by quantitative enzymelinked immunoassays kit (Quantikine Immunoassays, R\&D Systems, Minneapolis,
MN, USA) are based on the doubleantibody sandwich method. Results were expressed as $\mathrm{pg} / \mathrm{ml}$ or $\mathrm{ng} / \mathrm{ml}$ per milligram of tissue. MMP-9 concentrations were additionally measured in the sera of patients collected concomitantly to skin biopsies.

\section{Statistical analysis}

Data was entered into IBM compatible computer then analysis were done using SPSS $/ \mathrm{PC}^{+}$program for windows (Norusis, 1986). The following statistical procedures were performed (Saunders and Trapp,1990) arithmetic mean, standard deviation ( $\pm \mathrm{SD})$, " $F$ " test, one way ANOVA to test for variations within groups $(\mathrm{P}-$ values less than 0.05 were considered significant) and correlation coefficient " $r$ " (using spearman's rho) correlation is significant $(\mathrm{P}<0.01)$.

\section{Results}

Table $1 \&$ Figures $1-5$ show that there was a significant increase in TNF- $\alpha$, MMP-9, MMP-2, VEGF\& E-selectin concentrations $(\mathrm{P}<0.05)$ released in culture supernatants from the lesional tissue samples and significant increase in PASI score $(\mathrm{P}<0.001)$ in psoriatic patients with psoriatic arthritis (PsA) as compared to their levels in psoriatic patients without psoriatic arthritis. Table (1) also shows that there was a significant decrease in PASI score \& TNF- $\alpha$, MMP-9, MMP-2, VEGF\& E-selectin concentrations in psoriatic patients with and without psoriatic arthritis after 10 weeks of pioglitazone treatment as compared to their levels before pioglitazone treatment.

Table $2 \&$ Figure 6 show that there was a significant increase in serum MMP-9 levels $(\mathrm{P}<0.01)$ in psoriatic patients with psoriatic arthritis (PsA) as compared to their levels in psoriatic patients without psoriatic arthritis. Table 2 also shows that there was a significant decrease in serum MMP-9 in psoriatic patients with and without psoriatic arthritis after 10 weeks of pioglitazone treatment as compared to their levels before pioglitazone treatment. 
Table 3 shows significant positive correlations $(\mathrm{P}<0.01)$ between TNF- $\alpha$ \& PASI score and MMP-9, MMP-2, VEGF\& E-selectin released in tissue culture supernatants from the lesional tissue samples of psoriatic patients without psoriatic arthritis $(\mathrm{r}=0.9,0.74,0.45,0.59,0.48$ respectively) and after 10 weeks of pioglitazone treatment $(\mathrm{r}=.0 .87,0.68,0.53,0.61,0.51$ respectively).There are also significant positive correlations $(\mathrm{P}<0.01)$ between TNF- $\alpha$ \& PASI score and MMP-9, MMP-2, VEGF \& E-selectin released in tissue culture supernatants from the lesional tissue samples of patients with PsA ( $\mathrm{r}=0.76,0.71$, $0.52,0.57,0.52$ respectively) and after 10 weeks of pioglitazone treatment $(\mathrm{r}=0.85$, $0.84,0.58,0.63,0.67$ respectively).
Table 4 shows significant positive correlations $(\mathrm{P}<0.01)$ between MMP-9\& PASI score and MMP-2, VEGF \& Eselectin released in tissue culture supernatants from the lesional tissue samples of psoriatic patients without psoriatic arthritis $(\mathrm{r}=0.85,0.43,0.63,0.38$ respectively) and after 10 weeks of pioglitazone treatment $(\mathrm{r}=0.95,0.51,0.58,0.45$ respectively). There are also significant positive correlations $(\mathrm{P}<0.01)$ between MMP-9\& PASI score and MMP-2, VEGF\& E-selectin released in tissue culture supernatants from the lesional tissue samples of patients with PsA ( $\mathrm{r}=0.87,0.45,0.71,0.39$ respectively) and after 10 weeks of pioglitazone treatment $\quad(\mathrm{r}=0.82, \quad 0.39, \quad 0.69, \quad 0.41$ respectively). 
Table (1): Clinical characteristics and MMP-9, MMP-2, TNF- $\alpha$, VEGF\& E-selectin levels released in tissue culture supernatants from the lesional tissue samples of psoriatic patients with and without psoriatic arthritis before and after10 weeks of pioglitazone treatment.

\begin{tabular}{|c|c|c|c|c|c|}
\hline Parameters & $\begin{array}{l}\text { psoriatic patients } \\
\text { without PsA before } \\
\text { pioglitazone } \\
\text { treatment }\end{array}$ & $\begin{array}{l}\text { psoriatic patients } \\
\text { without PsA after } \\
\text { pioglitazone } \\
\text { treatment }\end{array}$ & $\begin{array}{l}\text { PsA patients } \\
\text { before } \\
\text { pioglitazone } \\
\text { treatment }\end{array}$ & $\begin{array}{c}\text { PsA patients after } \\
\text { pioglitazone } \\
\text { treatment }\end{array}$ & $\mathrm{P}<$ \\
\hline Age (years) & $44 \pm 12.2$ & $44 \pm 12.2$ & $45 \pm 11.5$ & $45 \pm 11.5$ & N.S \\
\hline BMI $(\mathrm{kg} / \mathrm{m} 2)$ & $28.4 \pm 5.9$ & $28.4 \pm 5.9$ & $29.6 \pm 6.4$ & $29.6 \pm 6.4$ & N.S \\
\hline $\begin{array}{l}\text { The duration of } \\
\text { Psoriasis (years) }\end{array}$ & $14.2 \pm 8.3$ & $14.2 \pm 8.3$ & $10.7 \pm 9.9$ & $10.7 \pm 9.9$ & ------ \\
\hline PASI score & $13.1 \pm 7.8$ & $6.4 \pm 2.9^{*}$ & $19.4 \pm 9.4^{*}$ & $8.4 \pm 5.6^{*}$ & 0.001 \\
\hline TNF- $\alpha(\mathrm{pg} / \mathrm{ml})$ & $216.5 \pm 117.4$ & $170.9 \pm 68.5^{*}$ & $299.5 \pm 125.2 *$ & $197.9 \pm 87.8^{*}$ & 0.05 \\
\hline MMP-9 (ng/ml) & $189.3 \pm 170.9$ & $46.8 \pm 63.7^{*}$ & $209.6 \pm 233.8^{*}$ & $63.3 \pm 84.9^{*}$ & 0.05 \\
\hline MMP-2 $(\mathrm{ng} / \mathrm{ml})$ & $1306 \pm 1081$ & $1017 \pm 1142 *$ & $1509 \pm 1073 *$ & $1191 \pm 1134 *$ & 0.05 \\
\hline VEGF (pg/ml) & $476.7 \pm 298.6$ & $230.6 \pm 250.1^{*}$ & $510.9 \pm 375.7 *$ & $240.8 \pm 270.9^{*}$ & 0.05 \\
\hline E-selectin (ng/ml) & $12.9 \pm 17.8$ & $5.1 \pm 3.8^{*}$ & $18.7 \pm 22.5^{*}$ & $4.5 \pm 3.2 *$ & 0.05 \\
\hline
\end{tabular}

Data are expressed as the mean $\pm \mathrm{SD}$

$*$ = Significant $(\mathrm{P}<0.05)$

Data are normalized per mg of tissue N.S = non significant

- MMP-9, MMP-2, TNF- $\alpha$, VEGF, E-selectin \& PASI score in psoriatic patients without PsA before pioglitazone treatment versus psoriatic patients without PsA after pioglitazone treatment, PsA patients before $\&$ after pioglitazone treatment.

- MMP-9, MMP-2, TNF- $\alpha$, VEGF, E-selectin \& PASI score in PsA patients before pioglitazone treatment versus psoriatic patients without PsA before \& after pioglitazone treatment and PsA patients after pioglitazone treatment.

- MMP-9, MMP-2, TNF- $\alpha$, VEGF, E-selectin \& PASI score in psoriatic patients with \&without PsA after pioglitazone treat-ment versus psoriatic patients with \& without PsA before pioglitazone treatment. 
Table (2): Serum MMP-9 in psoriatic patients with and without psoriatic arthritis before and after 10 weeks of pioglitazone treatment.

\begin{tabular}{|c|c|c|c|c|c|}
\hline Parameters & $\begin{array}{c}\text { psoriatic patients } \\
\text { without PsA } \\
\text { before } \\
\text { pioglitazone } \\
\text { treatment }\end{array}$ & $\begin{array}{c}\text { psoriatic patients } \\
\text { without PsA after } \\
\text { pioglitazone } \\
\text { treatment }\end{array}$ & $\begin{array}{c}\text { PsA patients } \\
\text { before } \\
\text { pioglitazone } \\
\text { treatment }\end{array}$ & $\begin{array}{c}\text { PsA patients after } \\
\text { pioglitazone } \\
\text { treatment }\end{array}$ & $\mathrm{P}<$ \\
\hline $\begin{array}{c}\text { Serum MMP-9 } \\
(\mathrm{ng} / \mathrm{ml})\end{array}$ & $208.7 \pm 45.6$ & $106.7 \pm 53.7^{*}$ & $452.4 \pm 62.4^{*}$ & $178.5 \pm 44.8^{*}$ & 0.01 \\
\hline
\end{tabular}

- Serum MMP-9 in psoriatic patients without PsA before pioglitazone treatment versus psoriatic patients without PsA after pioglitazone treatment, PsA patients before \& after pioglitazone treatment

- Serum MMP-9 in PsA patients before pioglitazone treatment versus psoriatic pati-ents without PsA before \& after pioglit-azone treatment and PsA patients after pioglitazone treatment.

- Serum MMP-9 in psoriatic patients with \&without PsA after pioglitazone trea-tment versus psoriatic patients with \& without PsA before pioglitazone treatment.

Table (3): Correlation between TNF- $\alpha$ \& PASI score and MMP-9, MMP-2, VEGF\& Eselectin released in tissue culture supernatants from the lesional tissue samples of psoriatic patients with and without psoriatic arthritis before and after 10 weeks of pioglitazone treatment.

\begin{tabular}{|l|c|c|c|c|}
\hline Parameters & $\begin{array}{c}\mathrm{r} \\
\text { psoriatic patients } \\
\text { without PsA before } \\
\text { pioglitazone } \\
\text { treatment }\end{array}$ & $\begin{array}{c}\mathrm{r} \\
\text { psoriatic patients } \\
\text { without PsA after } \\
\text { pioglitazone } \\
\text { treatment }\end{array}$ & $\begin{array}{c}\mathrm{r} \\
\text { PsA patients before } \\
\text { pioglitazone } \\
\text { treatment }\end{array}$ & $\begin{array}{c}\mathrm{r} \\
\text { PsA patients after } \\
\text { pioglitazone } \\
\text { treatment }\end{array}$ \\
\hline TNF- $\alpha$ \& PASI score & $0.9^{*}$ & $0.87^{*}$ & $0.76^{*}$ & $0.85^{*}$ \\
\hline TNF- $\alpha$ \& MMP-9 & $0.74^{*}$ & $0.68^{*}$ & $0.71^{*}$ & $0.84^{*}$ \\
\hline TNF- $\alpha$ \& MMP-2 & $0.45^{*}$ & $0.53^{*}$ & $0.52^{*}$ & $0.58^{*}$ \\
\hline TNF- $\alpha$ \& VEGF & $0.59^{*}$ & $0.61^{*}$ & $0.57^{*}$ & $0.63^{*}$ \\
\hline TNF- $\alpha$ \& E-Selectin & $0.48^{*}$ & $0.51^{*}$ & $0.52^{*}$ & $0.67^{*}$ \\
\hline
\end{tabular}

$\mathrm{r}=$ correlation coefficient $\quad *=$ Significant $(\mathrm{P}<0.01)$

Table (4): Correlation between MMP-9 \& PASI score and MMP-2, VEGF\& E-selectin released in tissue culture supernatants from the lesional tissue samples of psoriatic patients with and without psoriatic arthritis before and after 10 weeks of pioglitazone treatment.

\begin{tabular}{|l|c|c|c|c|}
\hline Parameters & $\begin{array}{c}\mathrm{r} \\
\text { psoriatic patients } \\
\text { without PsA before } \\
\text { pioglitazone } \\
\text { treatment }\end{array}$ & $\begin{array}{c}\mathrm{r} \\
\text { psoriatic patients } \\
\text { without PsA after } \\
\text { pioglitazone } \\
\text { treatment }\end{array}$ & $\begin{array}{c}\mathrm{r} \\
\text { PsA patients before } \\
\text { pioglitazone } \\
\text { treatment }\end{array}$ & $\begin{array}{c}\mathrm{r} \\
\text { PsA patients after } \\
\text { pioglitazone } \\
\text { treatment }\end{array}$ \\
\hline MMP-9\& PASI score & $0.85^{*}$ & $0.95^{*}$ & $0.87^{*}$ & $0.82^{*}$ \\
\hline MMP-9\& MMP-2 & $0.43^{*}$ & $0.51^{*}$ & $0.45^{*}$ & $0.39^{*}$ \\
\hline MMP-9\& VEGF & $0.63^{*}$ & $0.58^{*}$ & $0.71^{*}$ & $0.69^{*}$ \\
\hline MMP-9\& E-Selectin & $0.38^{*}$ & $0.45^{*}$ & $0.39^{*}$ & $0.41^{*}$ \\
\hline \multicolumn{2}{|c|}{$\mathrm{r}=$ correlation coefficient } & $*=$ Significant $(\mathrm{P}<0.01)$ &
\end{tabular}


Fig (1): TNF- $\alpha$ levels released in tissue culture supernatants from the lesional tissue samples of psoriatic patients with and without psoriatic arthritis before and after 10 weeks of pioglitazone treatment.

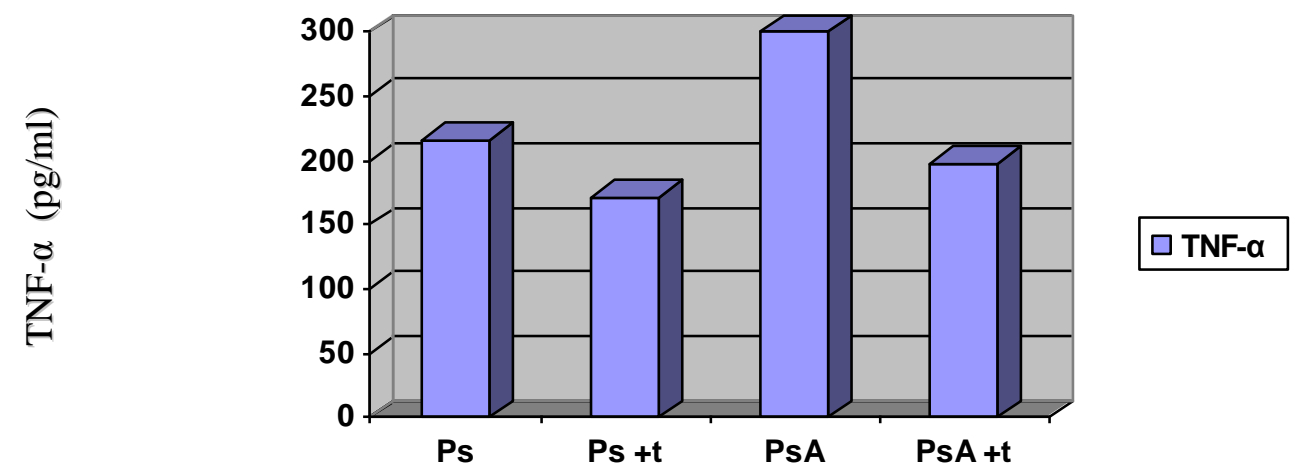

$\mathrm{Ps}=$ psoriatic patients without psoriatic arthritis

Ps $+\mathrm{t}=$ psoriatic patients without psoriatic arthritis

after pioglitazone treatment

PsA = psoriatic patients with psoriatic arthritis

PsA $+\mathrm{t}=$ psoriatic patients with psoriatic arthritis

after pioglitazone treatment

Fig (2): MMP-9 levels released in tissue culture supernatants from the lesional tissue samples of psoriatic patients with and without psoriatic arthritis before and after 10 weeks of pioglitazone treatment.

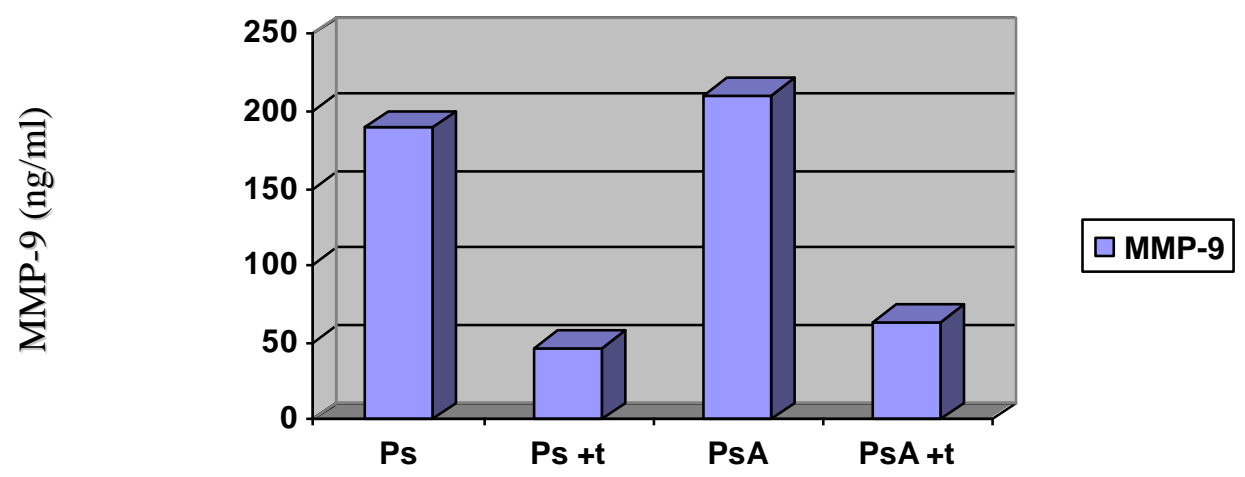


Fig (3): MMP-2 levels released in tissue culture supernatants from the lesional tissue samples of psoriatic patients with and without psoriatic arthritis before and after 10 weeks of pioglitazone treatment.

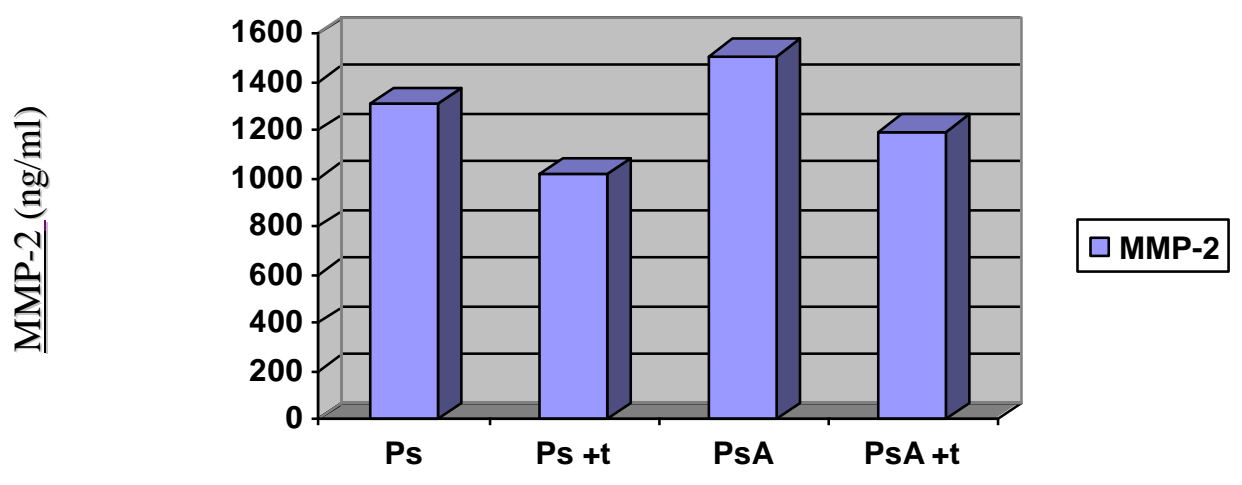

Fig (4): VEGF levels released in tissue culture supernatants from the lesional tissue samples of psoriatic patients with and without psoriatic arthritis before and after 10 weeks of pioglitazone treatment.

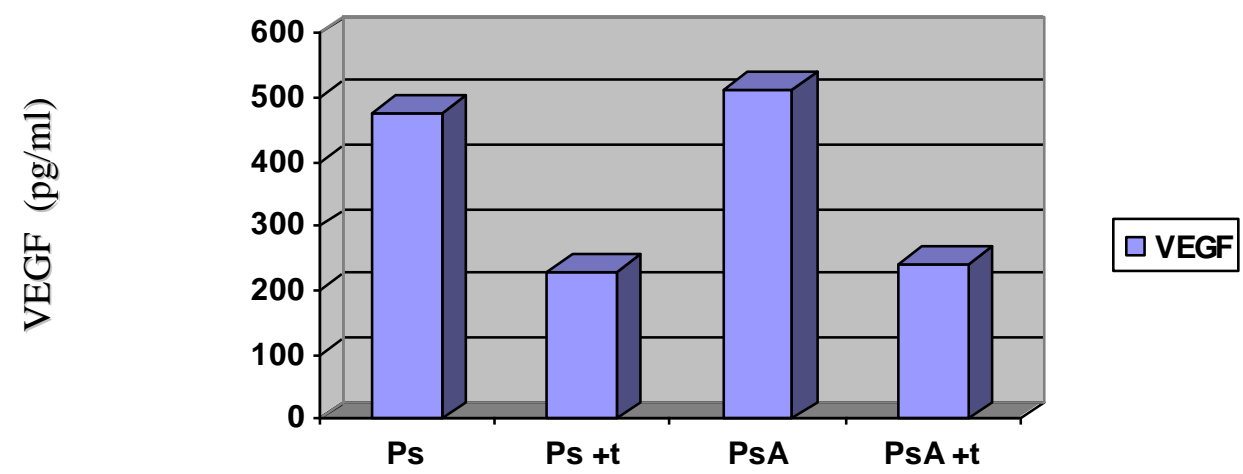

Fig (5): E-selectin levels released in tissue culture supernatants from the lesional tissue samples of psoriatic patients with and without psoriatic arthritis before and after 10 weeks of pioglitazone treatment

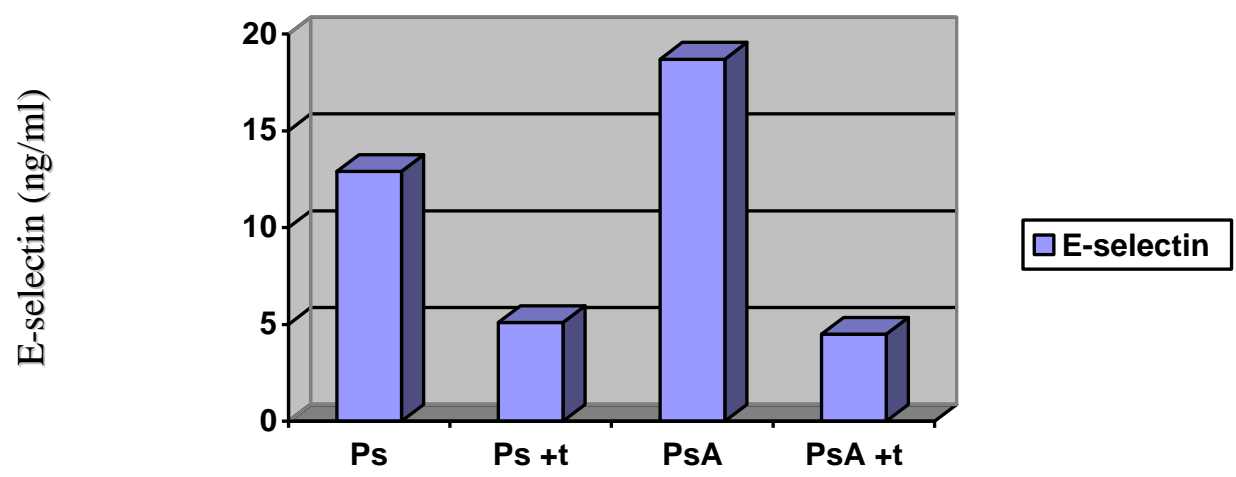


Fig (6): Serum MMP-9 levels in psoriatic patients with and without psoriatic arthritis before and after 10 weeks of pioglitazone treatment

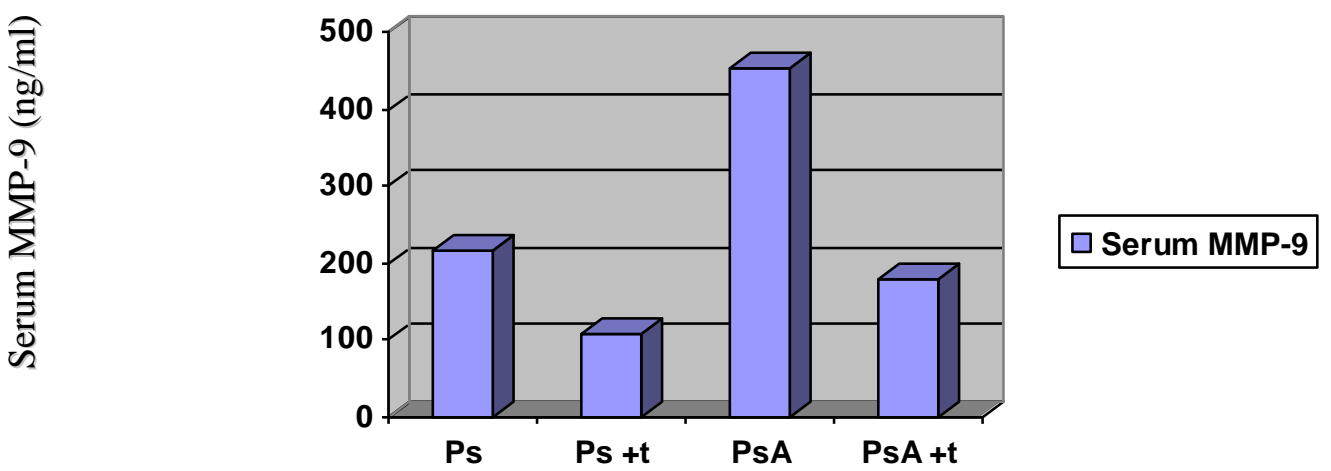

\section{Discussion}

Disordered differentiation and hyperproliferation of keratinocytes with inflammation are the hallmarks of psoriasis. Inflammation represents an early and key event in the development of both the cutaneous psoriasis and psoriatic arthritis. Compelling evidences indicate that the production of tumor necrosis factor- $\alpha$ $(\mathrm{TNF}-\alpha)$ plays a central role in psoriasis by sustaining the inflammatory process in the skin as well as in the joints. Among the multiple effects produced by TNF- $\alpha$ on keratinocytes, the induction of matrix metalloproteinase-9 (MMP-9), a collagenase implicated in joint inflammatory arthritis which acts as an angiogenesis promoting factor, might represent a key mechanism in the pathogenesis of the disease (Cordiali-Fei et al., 2006). Our results demonstrate that TNF- $\alpha$, MMP-9, MMP-2, VEGF\& E-selectin concentrations released in culture supernatants from the lesional tissue samples and serum MMP-9 levels in psoriatic patients with psoriatic arthritis (PsA) were significantly elevated as compared with psoriatic patients without psoriatic arthritis. TNF- $\alpha$ is considered a key cytokine regulator in psoriasis (Victor et al., 2003). As expected, the lesional amounts of TNF- $\alpha$ were directly correlated with the PASI score, sustaining its pathogenic role in the development of skin psoriasis. The correlation found between MMP-9 and PASI, suggests that also this molecule may be involved in the inflam- matory process leading to the cutaneous lesions. Indeed, TNF- $\alpha$ act as a potent inducer of MMP-9 in keratinocytes (Tomohiro et al., 2004). Therefore, TNF- $\alpha$ mediated induction of MMP-9 could be responsible of the overexpression and activity of this molecule as found in the synovial cells and skin of patients with PsA (Hitchon et al., 2002, Giannelli et al., 2004 \& Kane et al., 2004). On the other hand, MMP-9 can be also secreted by inflammatory cells, such as neutrophils, upon activation by the IL-8 family proteins (Chakrabarti \& Patel, 2005). Moreover, MMP-9 mediates terminal cleavage of IL-8, thus potentiating IL-8-induced activation of neutrophils. This suggests that MMP-9 can be involved as a mediator of the IL-8induced inflammatory process in the psoriatic skin (Van de Steen et al., 2000). Other data obtained by immunohistochemical analysis of psoriatic skin and synovia in individuals under infliximab treatment showed that the drug decreased the neoangiogenesis and reduced the activation of the endothelial cells resulting in decreased cell infiltration and clinical improvement (Goedkoop et al., 2004).

Thiazolidinediones (TZDs) are important new drugs, presently indicated for the treatment of type 2 diabetes but with a spectrum of properties which suggests their potential for treating a number of degenerative inflammatory diseases. At the 
tissue level, TZDs improve vascular endothelial function, and reduce the rate of progression of intimal-medial thickening of the carotid artery and the microalbuminuria of type 2 diabetes. Further, TZDs have been shown to be efficacious in inflammatory diseases as wide-ranging as psoriasis, ulcerative colitis and non-alcoholic steatohepatitis (Buckingham, 2005). Bhagavathula et al. (2004) observed that pioglitazone and rosiglitazone (potent TZDs) inhibited proliferation and motility as well as elaboration of MMP-1 and MMP-9. Inhibition was obtained with keratinocytes in monolayer culture and human skin in organ culture. Because enhanced keratinocyte motility and increased MMP production as well as increased keratinocyte proliferation are thought to contribute to the phenotype of psoriatic lesional skin, they propose that interference with these keratinocyte responses contributes to the previously reported antipsoriatic activity of TZD. In the present study we found that the clinical improvement of the skin expression of the disease in patients with and without psoriatic arthritis under pioglitazone therapy significantly correlated with the decrease of lesional MMP-9 in association with the decrease of TNF- $\alpha$, or VEGF and E-selectin, bioactive molecules already known to be implicated in the pathogenesis and clinical activity of the disease (Bonifati \& Ameglio 1999). Activation of peroxisome proliferator activated receptor gamma (PPAR gamma) by rosiglitazone or pioglitazone significantly reduced TNF-alpha and PMA induced MMP-9 gelatinolytic activity, but did not alter the expression of tissue inhibitor of MMPs type 1 (TIMP-1), the local inhibitor of MMP-9 (Hetzel et al., 2003). Liu et al. (2003) observed that treatment of the highly aggressive human breast cancer cell line MDA-MB-231 with the synthetic PPARgamma ligands pioglitazone or rosiglitazone, at concentrations at which no obvious cytotoxicity was observed in vitro, led to a significant inhibition of MMP-9 activities. They suggest that PPARgamma ligands may have therapeutic value for the treatment of highly invasive breast cancer by targeting its invasive behavior.

\section{Conclusion}

The current study shows the existence of a direct relationship between MMP-9 and $\mathrm{TNF}-\alpha$ production strongly suggesting that MMP-9 may play a key role in the skin inflammatory process. Our findings also demonstrating that pioglitazone could be considered as an efficacious and safe agent for the treatment of psoriasis. The optimum dose and duration of pioglitazone therapy remain to be determined.

\section{References}

1. Alenius GM, Jonsson S, Wallberg Jonsson S, et al. (2001): Matrix metalloproteinase-9 (MMP-9) in patients with psoriatic arthritis and rheumatoid arthritis. Clin Exp Rheumatol., 19:760.

2. Antoni CE, Kavanaugh A, Kirkham B, et al. (2005): Sustained benefits of infliximab therapy for dermatologic and articular manifestations of psoriatic arthritis: results from the infliximab multinational psoriatic arthritis controlled trial (IMPACT). Arthritis Rheum ., 52:1227-36.

3. Bhagavathula $\mathbf{N}$, Nerusu KC, Nerusu $\mathrm{KC}$, et al. (2004): Rosiglitazone inhibits proliferation, motility, and matrix metalloproteinase production in keratinocytes. J Invest Dermatol ., 122(1):130-9.

4. Bonifati C, and Ameglio F (1999): Cytokines in psoriasis. Int J Dermatol ., 38:248-251.

5. Bos JD, and De Rie MA (1999): The pathogenesis of psoriasis: immunological facts and speculations. Immunol Today ., 20:40-46.

6. Brandt $\mathbf{J}$ and Braun $\mathbf{J}$ (2006): Anti-TNF$\alpha$ agents in the treatment of psoriatic arthritis. Expert Opin Biol Ther ., 6: 99107.

7. Brushan M, McLaughlin B, Weiss JB and Griffiths CEM (1999): Levels of endothelial cell stimulating angiogenesis 
factor and vascular endothelial growth factor are elevated in psoriasis. $\mathrm{Br} \mathrm{J}$ Dermatol ., 141:1054-1060.

8. Buckingham RE (2005): Thiazolidinediones: Pleiotropic drugs with potent anti-inflammatory properties for tissue protection. Hepatol. Res., 33(2):167-70.

9. Camp, RDR (1998): Psoriasis. In: Champion RH, Burton JL, Burns DA, Breathrnach SM., editor. Textbook of Dermatology. 6. Oxford: Blackwell. p. 1631.

10. Carducci M, Mussi A, Bonifati C, et al. (1999): Correlation of skin corneometry values with serum E-selectin levels with disease severity in patients affected by plaque-type psoriasis: recovery after effective therapy. J. Dermatol., 22:475479.

11. Chakrabarti S, and Patel KD (2005): Regulation of matrix metalloproteinase-9 release from IL-8 stimulated human neutrophils. J Leukoc Biol ;78:279-288.

12. Christophers E (2006): Comorbidities in psoriasis. J Eur Acad Dermatol Venereol., 20 (s2):52-55.

13. Cordiali-Fei P, Trento E, D'Agosto G, et al. (2006): Decreased levels of metalloproteinase-9 and angiogenic factors in skin lesions of patients with psoriatic arthritis after therapy with anti-TNF- $\alpha$. J. Autoimmune Dis., 3:5.

14. Fraser A,Fearon U,Reece R, et al.( 2001): Matrix metalloproteinase-9, apoptosis and vascular morphology in early arthritis. Arthritis Rheum ., 44:2024-2028.

15. Fredriksson $T$ and Pettersson $U$ (1978): Severe psoriasis-oral therapy with a new retinoid. Dermatologica ., 157:238-244.

16. Galadari H, Fuchs B, and Lebwohl $M$ (2003): Newly available treatments for psoriatic arthritis and their impact on skin psoriasis. Int J Dermatol ., 42:231-237.

17. Giannelli G, Erriquez R, Iannone F, et al. (2004): MMP-2, MMP-9, TIMP-1 and TIMP-2 levels in patients with rheumatoid arthritis and psoriatic arthritis. Clin Exp Rheumatol ., 22:335-338.

18. Gladman, DD and Rahman, $P$ (2001): Psoriatic Arthritis. In: Harris ED, Sledge CB, Budd RC, Sergent JS. , editor. Textbook of Rheumatology. 6. Philadelphia: W.B. Saunders Co., 1071-1079.

19. Goedkoop AY, Kraan MC, Picavet DI, et al. (2004): Deactivation of endothelium and reduction in angiogenesis in psoriatic skin and synovium by low dose infliximab therapy in combination with stable methotrexate therapy: a prospective single- cen-tre study. Arthritis Res Ther ., 6:R32634.

20. Gottlieb AB (2003): Infliximab for psoriasis. J Am Acad Dermatol ., 49:S112S117.

21. Gottlieb AB, Evans R, Li S, Dooley LT, et al.( 2004): Infliximab induction therapy for patients with severe plaque-type psoriasis: a randomized, double-blind, placebocontrolled trial. J Am Acad Dermatol., 51: 534-42.

22. Hata H, Sakaguchi N, Yoshitomi H, et al. (2004): Distinct contribution of IL-6, TNF$\alpha$, IL-1, and IL-10 to T cell-mediated spontaneous autoimmune arthritis in mice. Clin Invest., 114:582-588.

23. Helliwell PS and Taylor WJ (2005): Classification and diagnostic criteria for psoriatic arthritis. Ann Rheum Dis ., 64:ii 3-ii 8.

24. Hetzel M, Walcher D, Grub M, et al. (2003): Inhibition of MMP-9 expression by PPARgamma activators in human bronchial epithelial cells. Thorax ;58(9):778-83.

25. Hitchon CA, Danning CL, Illei GG, et al. (2002): Gelatinase expression and activity in the synovium and skin of patients with erosive psoriatic arthritis. J. Rheumatol; 29:107-117.

26. Itoh T, Matsuda H, Tanioka M, et al. (2002): The role of matrix metalloproteinase-2 and matrix metalloproteinase- 9 in antibody induced arthritis.J Immunol ., 169:2643-2647.

27. Johnston A, Gudjonsson JE, Sgmundsdottir H,et al. (2004): Peripheral blood $\mathrm{T}$ cell responses to keratin peptides that share sequences with streptococcal $\mathrm{M}$ proteins are largely restricted to skin homing CD8+ T cells. Clin Exp Immunol ., 138:83-93.

28. Kane D, and Fitzgerald $O$ (2004): Tumor necrosis factor alpha in psoriasis and psoriatic arthritis: a clinical, genetic and histopathologic perspectives. Curr Rheumatol Rep ;6:292-298.

29. Kane D, Jensen LE, Grehan S, et al. (2004): Quantitation of metalloproteinase gene expression in rheumatoid and psoriatic arthritis synovial tissue distal and proximal to the cartilage-pannus junction. J Rheumatol;31:1274-1280.

30. Krueger G and Callis K (2004): Potential of tumor necrosis factor inhibitors in psoriasis and psoriatic arthritis. Arch Dermatol; 140:218-225.

31. Kurebayashi S, Xu X, Ishii S, et al. ( 2005): A novel thiazolidinedione MCC- 
555 down-regulates tumor necrosis factoralpha-induced expression of vascular cell adhesion molecule-1 in vascular endothelial cells. Atherosclerosis ;182(1):71-7.

32. Liu H, Zang C, Fenner MH, et al. (2003): PPARgamma ligands and ATRA inhibit the invasion of human breast cancer cells in vitro. Breast Cancer Res Treat_;79(1):6374.

33. Liu Y, Krueger JG, and Bowcock AM (2006): Psoriasis: genetic associations and immune system changes. Genes Immun ;9: 6364351.

34. Lockslay RM, Killeen N, Leonardo MJ (2001): The TNF and TNF receptors superfamilies: integrating mammalian biology. Cell ;104:487-501.

35. Mackay AR, Hartzler JL, Pelina MD, Thorgeirsson UP (1990): Studies on the ability of $65-\mathrm{kDa}$ and $92-\mathrm{kDa}$ tumor cell gelatinases to degrade type IV collagen. J Biol Chem;265:21929-21934.

36. Mastroianni A, Minutilli E, Mussi A et al. (2005): Cytokine profiles during inflixamb monotherapy in psoriatic arthritis. Br J Dermatol ;153:531-536.

37. McHugh NJ, Balachrishnan C, and Jones SM (2003): Progression of peripheral joint disease in psoriatic arthritis: a 5-year prospective study. Rheumatology (Oxford) ;42:778-783.

38. Mease PJ, Goffe BS, Metz J et al. (2000): Etanercept in the treatment of psoriatic arthritis and psoriasis: a randomised trial. Lancet ;356:385-390.

39. Nickoloff BJ, Mitra RS, Elder JT et al. (1989): Decreased growth inhibition by recombinant $\gamma$ interferon is associated with increased trnsforming growth factor-alpha production in keratinocytes cultured from psoriatic lesions. Br J Dermatol ;121:161174.

40. Norusis MJ. SPSS/PC ${ }^{+}$program manual. Chicago PSS Incorporation, 1986.

41. Parks WC, Wilson CL, Lopez-Boado YS (2004): Matrix metalloproteinases as modulators of inflammation and innate immunity. Nature Immunology Review ;4:617-629.

42. Pilcher BK, Wang M, Qin XJ, et al., (1999): Role of matrix metalloproteinases and their inhibition in cutaneous wound healing and allergic contact hypersensitivity. Ann N Y Acad Sci ;878:12-24.
43. Ritchlin CT, Haas-Smith SA, Li P, Hicks DG, Schwarz EM (2003): Mechanisms of TNF- $\alpha$-and RANKL-mediated osteoclastogenesis and bone resorption in psoriatic arthritis. J Clin Invest ;111:821-831.

44. Sano S, Chan KS, Carbajal S, et al. (2005): Stat 3 links activated keratinocytes and immunocytes required for development of psoriasis in a novel transgenic mouse model. Nature Med;11:43-49.

45. Saunders BD and Trapp RG. ( 1990): Basic and clinical biostatistics. New Jersey: Prentice Hall International Inc, 44, 46,104,163-4.

46. Schopf RE, Aust H, Knop J (2002): Treatment of psoriasis with the chimeric monoclonal antibody against tumor necrosis factor alpha, infliximab. $\mathrm{J}$ Am Acad Dermatol ;46:886-891.

47. Shafiq N, Malhotra S, Pandhi P, et al. (2005): Pilot trial: Pioglitazone versus placebo in patients with plaque psoriasis (the P6). Int J Dermatol ;44(4):328-33.

48. Shiina T, Inoko H, Kulski JK(2004): An update of the HLA genomic region, locus information and disease associations. Tissue Antigens ;64(6):631-49.

49. Suomela S, Kariniemi AL, Impola U, et al. (2003): Matrix metalloproteinase-19 is expressed by keratinocytes in psoriasis. Acta Derm Venereol ;83(2):108-14.

50. Tomohiro B, Gazel A, Blumemberg $\mathbf{M}$ (2004): Effects of Tumor Necrosis Factor- $\alpha$ (TNF- $\alpha$ ) in epidermal keratinocytes revealed using global transcripional profiling. J. Biol. Chem ;279:32633-32642.

51. Van de Steen PE, Proost P, Wuyts A, et al. (2000): Neutrophil gelatinase B potentiates interleukin- 8 tenfold by aminoterminal processing, whereas it degrades CTAP-III, PF-4 and GRO-alpha and leaves RANTES and MCP-2 intact. Blood ., 96:2673-2681.

52. Victor FC, Gottlieb AB, Menter A (2003): Changing paradigms in dermatology: tumor necrosis factor alpha (TNFalpha) blockade in psoriasis and psoriatic arthritis. Clin Dermatol;21:392-397.

53. Wrone-Smith T, Mitra RS, Thompson CB, et al. (1997): Keratinocytes derived from psoriatic plaques are resistant to apoptosis compared with normal skin. Am J Pathol;151:1321-1329. 


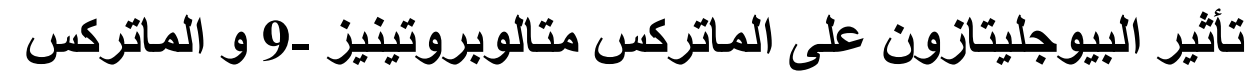

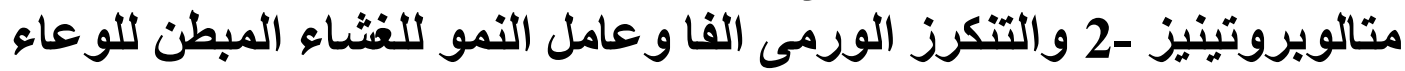

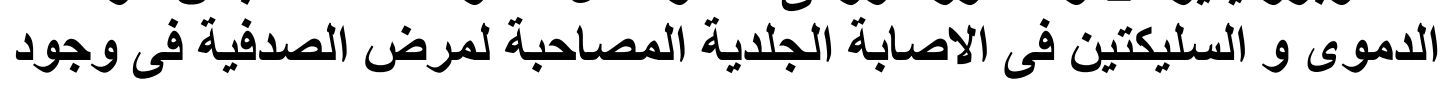
وعدم وجود التهاب المفاصل التهل المدئل

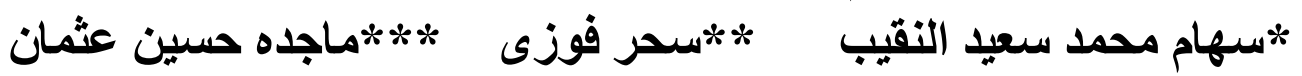

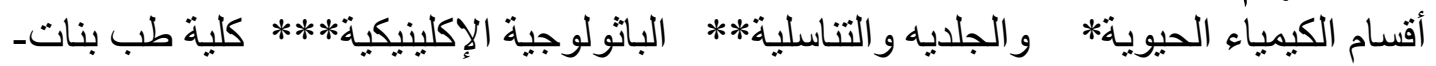
جامعة الأز هر

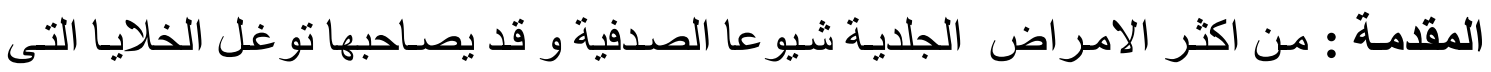

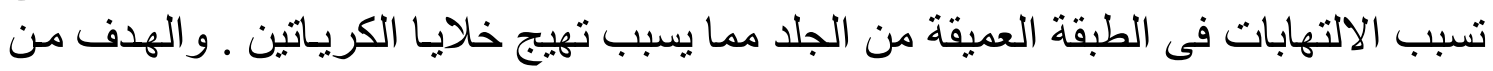

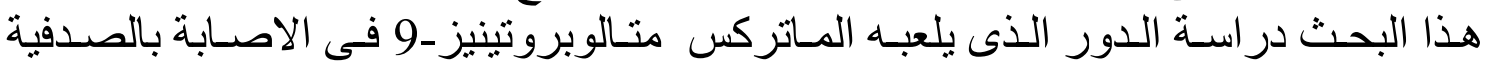

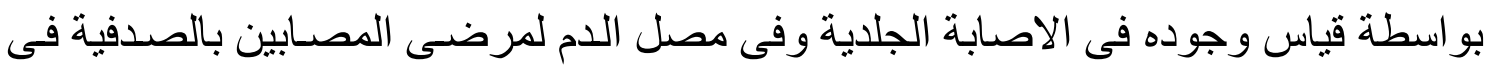

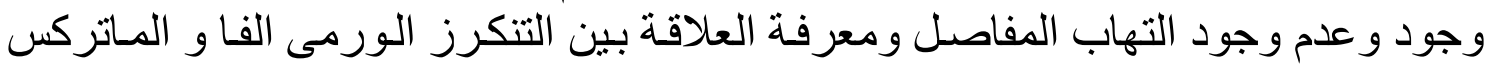

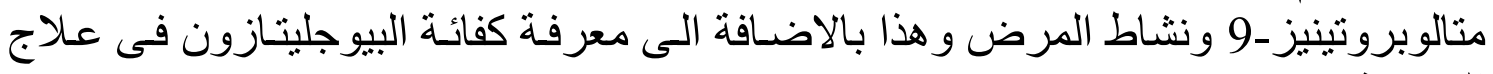

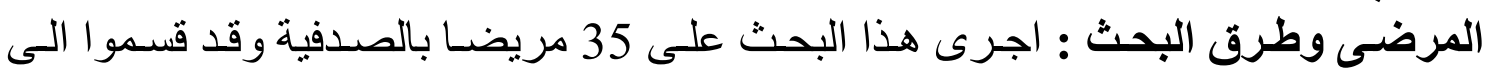

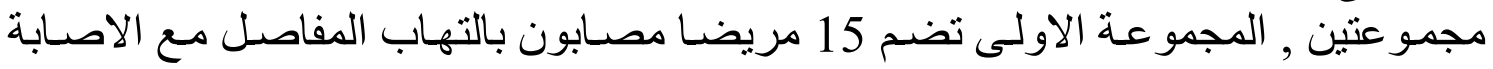

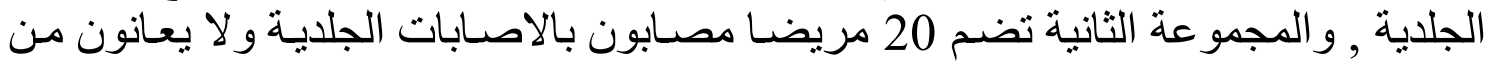

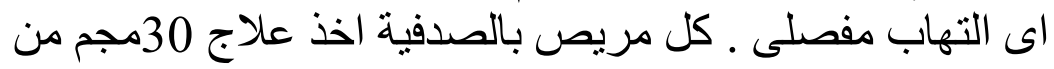

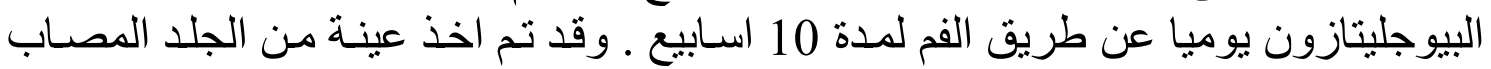

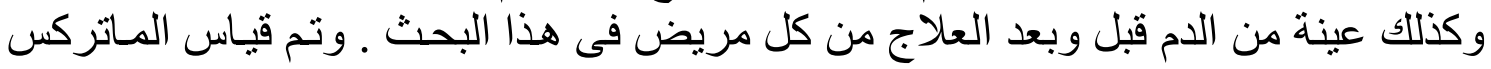

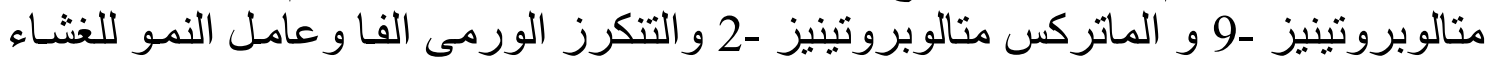

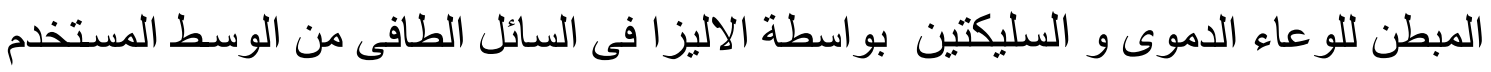

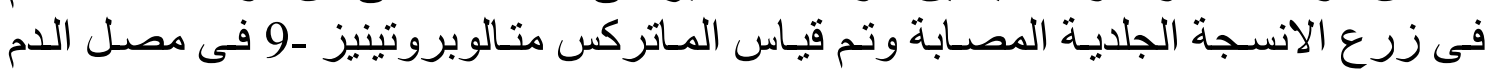

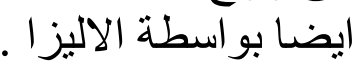

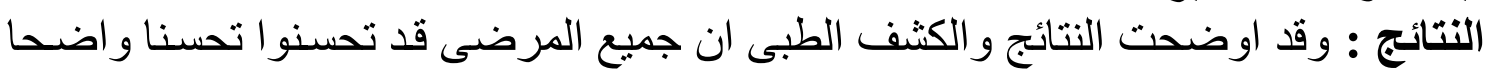

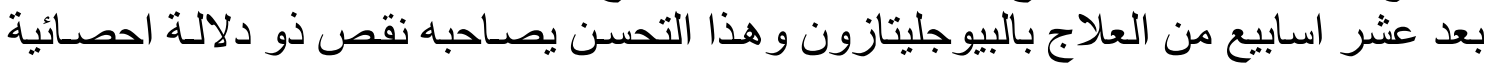

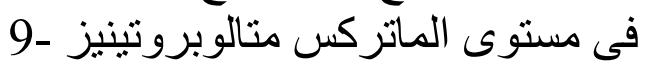
و الماتركس متالوبروتينيز -2 و التنكرز الوريز الورمى الفاو عامل النمو للغشـاء المبطن للوعاء

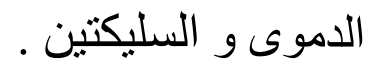
وقد وجد ارتباطا ذو دلالة احصائية بين المستركس متالوبروتينيز -9 و التنكرز الورمى الفا

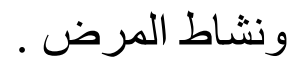

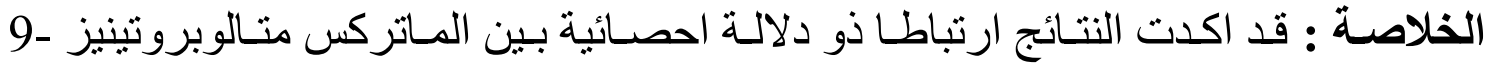

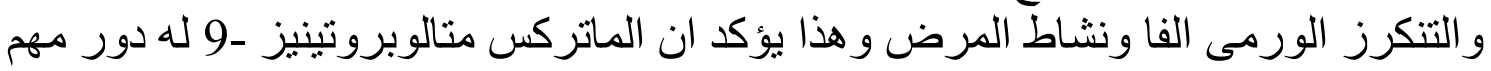

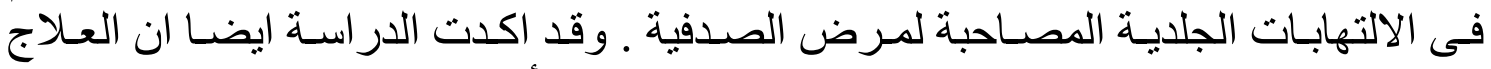

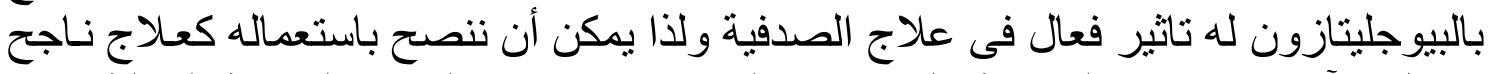

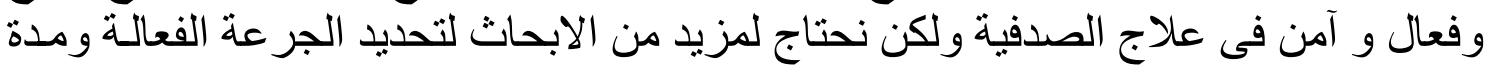
العلاج اللازمة لعلاج الصدفية الصنية 